\title{
The expanding regulatory universe of p53 in gastrointestinal
}

\section{cancer [version 1; peer review: 2 approved]}

\author{
Andrew Fesler ${ }^{1}$, Ning Zhang ${ }^{2}$, Jingfang Ju ${ }^{1}$ \\ ${ }^{1}$ Translational Research Laboratory, Department of Pathology, Stony Brook University, Stony Brook, USA \\ 2Department of Pharmacy, Dalian Medical University, Dalian, China
}

\section{V1 First published: 26 Apr 2016, 5:756 \\ https://doi.org/10.12688/f1000research.8363.1}

Latest published: $26 \mathrm{Apr}$ 2016, 5:756

https://doi.org/10.12688/f1000research.8363.1

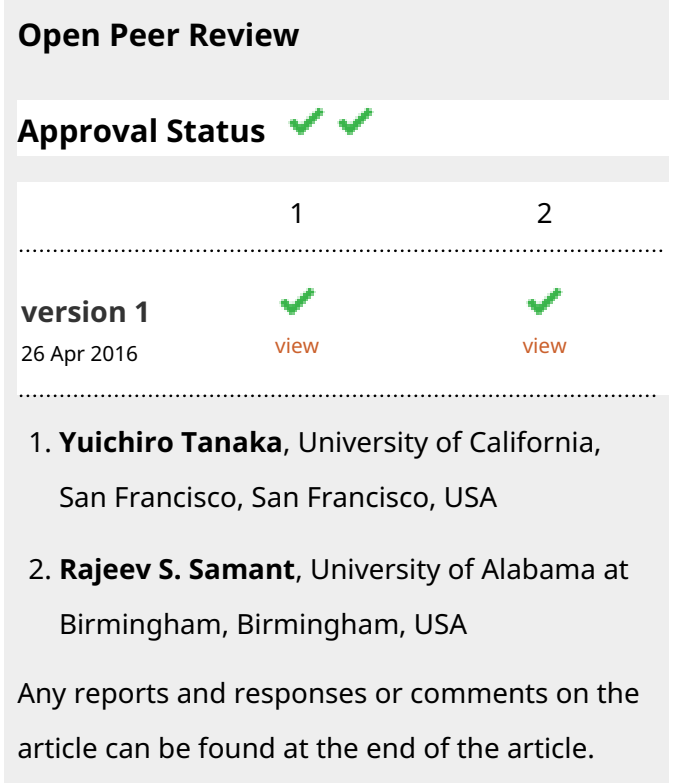

\begin{abstract}
Tumor suppresser gene TP53 is one of the most frequently deleted or mutated genes in gastrointestinal cancers. As a transcription factor, p53 regulates a number of important protein coding genes to control cell cycle, cell death, DNA damage/repair, stemness, differentiation and other key cellular functions. In addition, p53 is also able to activate the expression of a number of small non-coding microRNAs (miRNAs) through direct binding to the promoter region of these miRNAs. Many miRNAs have been identified to be potential tumor suppressors by regulating key effecter target mRNAs. Our understanding of the regulatory network of p53 has recently expanded to include long non-coding RNAs (IncRNAs). Like miRNA, IncRNAs have been found to play important roles in cancer biology. With our increased understanding of the important functions of these non-coding RNAs and their relationship with p53, we are gaining exciting new insights into the biology and function of cells in response to various growth environment changes. In this review we summarize the current understanding of the ever expanding involvement of noncoding RNAs in the p53 regulatory network and its implications for our understanding of gastrointestinal cancer.
\end{abstract}

Keywords

p53, non-coding RNA, gastrointestinal cancer

\footnotetext{
Corresponding author: Jingfang Ju (Jingfang.Ju@stonybrookmedicine.edu)

Competing interests: No competing interests were disclosed.

Grant information: This study was supported by National Institute of Health/National Cancer Institute R01CA155019 (J. Ju), R33CA147966 (J. Ju).

The funders had no role in study design, data collection and analysis, decision to publish, or preparation of the manuscript.

Copyright: ( 2016 Fesler A et al. This is an open access article distributed under the terms of the Creative Commons Attribution License, which permits unrestricted use, distribution, and reproduction in any medium, provided the original work is properly cited.
}

How to cite this article: Fesler $A$, Zhang $N$ and Ju J. The expanding regulatory universe of p53 in gastrointestinal cancer [version 1; peer review: 2 approved] F1000Research 2016, 5:756 https://doi.org/10.12688/f1000research.8363.1

First published: 26 Apr 2016, 5:756 https://doi.org/10.12688/f1000research.8363.1 


\section{Introduction}

The discovery of p53 is one of the most exciting events in biological research over the past 30 years $^{1-3}$. The field of p53 research represents a large growing body of exciting studies with over 75000 citations in PubMed. p53 is one of the most frequently mutated or deleted tumor suppressor genes in gastrointestinal (GI) cancers which represent nearly $30 \%$ of tumor incidences. It is well established that the classical function of tumor suppressor gene p53 is to act as a transcription factor to regulate its downstream protein coding genes in response to various growth conditions and cellular stresses ${ }^{4,5}$. Most of the research effort in the past has been devoted to the regulatory mechanism of transcriptional regulation of protein coding genes by p53. Independent of its transcriptional function, $\mathrm{p} 53$ is also able to regulate cell death by migrating directly to the mitochondria and interacting with B-cell lymphoma 2 (BCL-2) family member proteins to induce mitochondrial outer membrane permeability ${ }^{6}$. Limited attention has been devoted to other p53 functions such as RNA binding and post-transcriptional control ${ }^{7}$. With the discovery of non-coding RNA such as microRNA (miRNA), we and others have recognized the importance of post-transcriptional control mediated by non-coding RNAs in cancer $^{8,9}$. Post-transcriptional and translational controls mediated by RNA binding proteins and non-coding RNAs provide cells with a great advantage in response to acute growth environment changes such as genotoxic stress caused by chemo- and/or radiationtherapy ${ }^{10-12}$. Non-coding RNAs comprise nearly $97 \%$ of transcribed RNA molecules ${ }^{13}$. Much of the research efforts in the past decade concerning non-coding RNAs have been focused on short noncoding RNAs such as miRNAs and piRNAs. However, with advances in sequencing technology, now there is a growing body of evidence showing that lncRNAs also contribute to gene regulation at multiple levels ${ }^{14,15}$. Perhaps not surprisingly, important interactions have been discovered between the functions and regulation of these non-coding RNAs and p53. The relationship between non-coding RNA and p53 has been revealed to be quite dynamic, with p53 regulating the expression of some non-coding RNAs while other non-coding RNAs can function to regulate p53. While our appreciation of the important functions of non-coding RNA has grown, we have achieved a much better understanding of non-coding RNAs in the p53 regulated mechanisms in cancer.

\section{p53 and miRNAs}

p53 is one of the most well studied tumor suppressor genes. Disruptions of 553 functions, via deletions or mutations are found in many different types of cancers, including over $50 \%$ of colorectal cancers ${ }^{16-18}$. The importance of p53 in cancers, is associated with its role as a transcriptional activator or suppressor, by which it regulates the expression of many essential genes. p53 function is crucial to maintain genome integrity and stability. p53 has been called the "guardian of the genome' ${ }^{19}$. It can also act as an RNA-binding protein to modulate gene expression at the posttranscriptional level. p53 binds to the 5'-UTR region of cyclindependent kinase 4 (CDK4) to suppress translation and it has been shown to auto-regulate its own translation by directly interacting with its own mRNA ${ }^{20,21}$.

miRNA are short non-coding RNA that are transcribed as primary miRNAs (pri-miRNA) ${ }^{22}$. The pri-miRNA is cleaved by Drosha to a
70 nucleotide stem-loop pre-miRNA. Pre-miRNA is transported to the cytoplasm by Exportin 5 and further cleaved by RNAse Dicer to a 20 to 25 base pair double stranded miRNA. miRNAs modulate expression of target mRNAs by either perfect or imperfect base pairing mainly at the 3'-UTR regions of mRNA transcripts to inhibit translation and/or promote mRNA degradation. One particular miRNA can regulate multiple mRNA transcripts providing the possibility for the regulation of multiple different cellular networks and pathways by an individual miRNA ${ }^{23}$. There are also multiple miRNAs that can directly interact with one particular mRNA. With the discovery of miRNAs and the fact that they can have important roles in cancer biology, as well as the well-established function of p53 in cancer, we reasoned that there may be some interplay between the two and some of these miRNAs may be involved in the $\mathrm{p} 53$ regulatory network. We first reported a systematic analysis of miRNA profiles in colon cancer cell lines, HCT 116, containing either wild type $\mathrm{p} 53$ or null $\mathrm{p} 53^{8}$. In this study, we also profiled actively translated mRNAs impacted by $\mathrm{p} 53$ loss, and bioinformatically identified putative p53-binding sites in nearly $40 \%$ of miRNA promoter regions (e.g. miR-34s, miR-192, miR-215, miR-194, miR-502, miR-200c, miR-26a, miR-15) ${ }^{8}$. Many of these miRNAs were found to be directly regulated by $\mathrm{p} 53$ by us and other groups, thus establishing the interplay between p53 and miRNA networks in cancer $^{24-30}$.

\section{miRNA regulation by $\mathrm{p} 53$}

Research by us and other groups has clearly demonstrated that regulation of miRNA is among the many important functions of p53 in the cell. The miRNAs that have been shown to be regulated by 553 have important roles in regulating cellular pathways and functions such as cell cycle, apoptosis and chemoresistance. Working with the miRNAs we identified as having putative p53 binding sites in their promoter region we validated that miR-26a was directly regulated by $\mathrm{p} 53$ in colon cancer ${ }^{8}$. miR-26a has been found to act as a tumor suppressor in mouse intestine ${ }^{31}$. In gastric cancer, miR-26a also seems to act as a tumor suppressor, by targeting fibroblast growth factor 9 (FGF9) and inhibiting cell proliferation and metastasis ${ }^{32}$. miR-34s are the most extensively investigated miRNAs shown to be directly regulated by p53 in a number of different tumor types ${ }^{28}$. miR-34a regulation by p53 is important in p53 mediated apoptosis, with inhibition of miR-34a reducing p53-induced apoptosis ${ }^{9}$. miR-34a suppresses the E2F transcription factor pathway, reducing cell cycle progression. miR-34a contributes to apoptosis regulation in colon cancer through targeting silent information regulator 1 (SIRT1). miR-34a also contributes to the activation of both p53 and p21. These functions contribute to the tumor suppressor role of miR-34a $\mathrm{a}^{9,28,33-35}$. miR-34 is directly regulated by p53 and is reduced in $36 \%$ of human colorectal cancer tumor specimens ${ }^{33}$. p53 dependent expression of miR-34 also inhibits tumor progression by disrupting an IL-6R/ Stat3/miR-34a feedback loop ${ }^{36}$. miR-34s have also been demonstrated to be important in other GI tumor types ${ }^{37}$. In gastric cancer, miR-34 expression can activate tumor suppressor pathways in cells that lack functional p53 as well as being able to inhibit tumorsphere formation ${ }^{38}$. miR-34 is one of the best characterized miRNAs that is regulated by $\mathrm{p} 53$ and has important functions in cancer, and thus not surprisingly, miR-34 based anti-cancer therapy also represents one of the first miRNAs to enter into clinical trials ${ }^{39}$. 
Beyond miR-34 as the poster child of p53 regulated miRNA, there are other important p53 regulated miRNAs. miR-192 and miR-215 have been shown by multiple groups to be regulated by p53 and their expression levels were reduced in colorectal cancer ${ }^{25,29,40,41}$. miR-192 and miR-215 can induce cell cycle arrest and enhance p53 mediated p21 expression when overexpressed in colon cancer cell lines. Our group has focused our efforts on investigating the roles of miR-192 and miR-215 in colorectal cancer with the interest of understanding chemoresistance mechanisms to 5-fluorouracil (5-FU) and methotrexate (MTX). We discovered that p53 and miR-192 form a positive feedback loop to regulate cell cycle and proliferation ${ }^{25}$. In addition, we discovered a key protein target of miR-192 is dihydrofolate reductase (DHFR). DHFR is a protein therapeutic target of MTX. miR-192 also suppresses the expression of 5-FU protein target thymidylate synthase (TYMS, TS). These results have also been reported by another research group $^{42}$. However, the function of miR-215 and miR-192 seems to be different in gastric cancer. It has been reported that the expression of miR-215 is up-regulated in gastric cancer and one of the key targets is tumor suppressor retinoblastoma gene $\mathrm{Rb} 1^{43}$. Consistent with this, another report shows that miR-192 and miR-215 are associated with gastric tumor invasion and lymph node metastasis ${ }^{44}$. It appears that depending on the cellular and disease context, miRNAs can target different sets of mRNAs, as a result, they can function as either tumor suppressors or oncogenes. The regulatory mechanism and function of miR-192/215 will be quite unique in colorectal cancer vs. gastric cancer. One recent study demonstrated the potential of miR-192, miR-215 and miR-194 as promising detection biomarkers for Barrett's esophagus $^{45}$, further supporting the importance of the p53 mediated miRNAs. miR-194 has also been identified as a p53 regulated miRNA. In colon cancer, miR-194 targets thrombospondin 1 (TSP-1) and is involved in promoting angiogenesis ${ }^{46}$. In gastric cancer, miR-194 has been shown to target E3 ubiquitin-protein ligase RBX1 and decrease proliferation and migration ${ }^{47}$. In contrast to these miRNAs, we have identified a negative correlation between miR-502 expression and p53, suggesting that rather than inducing the expression of miR-502, p53 inhibits its expression in colon cancer. miR-502 plays a role in regulating autophagy and proliferation in colon cancer cells ${ }^{24}$. miR-145 is also transcriptionally regulated by $\mathrm{p} 53$. miR-145 in turn suppresses the expression of cMyc and cyclin-dependent kinase 6 (CDK6), to inhibit cell proliferation and induce apoptosis ${ }^{48,49}$. miR-1204 is transcriptionally activated by p53 and also inhibits cellular proliferation ${ }^{50}$.

In addition to wild type p53, mutant p53 also plays key roles in GI cancer. Studies have demonstrated that the gain-of-function of mutant p53 is an important mechanism for tumors to develop resistance and impacts tumor progression ${ }^{51,52}$. In fact, mutant p53 can directly influence miRNA expression by interacting with miRNA promoters $^{53,54}$. Mutant p53 exerts oncogenic functions and promotes epithelial-mesenchymal transition (EMT) in endometrial cancer (EC) by directly binding to the promoter of miR-130b, a negative regulator of zinc finger E-box-binding homeobox 1 (ZEB-1), and inhibiting its transcription. miR-223 was recently found to be down-regulated directly by mutant p53 proteins in breast and colon cancer cell lines ${ }^{55}$. Mutant p53 binds the miR-223 promoter and reduces its transcriptional activity. Such regulation requires the transcriptional repressor ZEB-1. In addition, miR-223 exogenous expression sensitizes breast and colon cancer cell lines expressing mutant p53 to treatment with DNA-damaging drugs ${ }^{55}$. Let-7i has also been found to be regulated by mutant $\mathrm{p} 53$, inhibiting invasion and migration ${ }^{54}$. These results suggest that it will be important to identify additional miRNAs that are regulated by various mutant $\mathrm{p} 53$ proteins. Table 1 summarizes some p53 regulated miRNAs in GI cancer.

\begin{tabular}{|c|c|c|c|c|c|}
\hline miRNA & Wtp53/Mutp53 & $\begin{array}{c}\text { Transcriptional } \\
\text { Target }\end{array}$ & $\begin{array}{c}\text { Tumor Suppressor/ } \\
\text { Oncogene }\end{array}$ & Function & Ref. \\
\hline miR-26a & Wt & Yes & Tumor Suppressor & $\begin{array}{l}\downarrow \text { Proliferation } \\
\downarrow \text { Metastasis } \\
\uparrow \text { Apoptosis }\end{array}$ & $8,31,32$ \\
\hline miR-34 & Wt & Yes & Tumor Suppressor & $\begin{array}{c}\downarrow \text { Proliferation, } \uparrow \text { Cell Cycle } \\
\text { Arrest, } \uparrow \text { Apoptosis, } \\
\uparrow \text { Senescence, } \downarrow \text { Tumor } \\
\text { Sphere Formation, } \\
\downarrow \text { EMT }\end{array}$ & $\begin{array}{c}9,28,33-35 \\
38,110\end{array}$ \\
\hline $\begin{array}{l}\text { miR-192/ } \\
\text { miR-215 }\end{array}$ & Wt & Yes & * & $\begin{array}{c}\uparrow / \downarrow \text { Proliferation, } \\
\uparrow / \downarrow \text { Chemosensitivity, } \\
\uparrow \text { Cell Cycle Arrest }\end{array}$ & $25,29,42,44$ \\
\hline miR-194 & Wt & Yes & * & $\begin{array}{l}\downarrow \text { Proliferation, } \downarrow \text { Migration/ } \\
\text { Invasion, } \uparrow \text { Angiogenesis }\end{array}$ & 46,47 \\
\hline miR-502 & Wt & No & Tumor Suppressor & $\begin{array}{l}\downarrow \text { Autophagy, } \uparrow \text { Cell } \\
\text { Cycle Arrest }\end{array}$ & 24 \\
\hline miR-145 & Wt & Yes & Tumor Suppressor & $\downarrow$ Proliferation & 48,49 \\
\hline miR-1204 & Wt & Yes & Tumor Suppressor & $\begin{array}{c}\uparrow \text { Cell Cycle Arrest, } \\
\uparrow \text { Apoptosis }\end{array}$ & 50 \\
\hline miR-130b & Mut & No & Tumor Suppressor & $\downarrow$ LEMT & 53 \\
\hline miR-223 & Mut & No & Tumor Suppressor & $\downarrow$ Chemoresistance & 55 \\
\hline Let-7i & Mut & No & Tumor Suppressor & $\begin{array}{c}\downarrow \text { Migration/Invasion, } \\
\downarrow \text { Metastasis }\end{array}$ & 54 \\
\hline
\end{tabular}

*--Role not clear, or conflicting reports in different cancer types 


\section{p53 regulation by miRNA}

The relationship between p53 and miRNAs is more complex than just transcription regulation by $\mathrm{p} 53$. In fact, the interaction between the two is a two way street, with several miRNAs being able to regulate p53 expression either through direct targeting, or through regulation of other proteins that in turn modulate p53 expression and function. Some of the miRNAs regulated by p53 are actually able to act in feedback loops to regulate p53 as well. We investigated the regulation mechanism of $\mathrm{p} 53$ by miR-215 in colorectal cancer and discovered that a key target of miR-215 is denticleless protein homolog (DTL). The suppression of DTL by miR-215 triggered an up-regulation of p53 and p2 $1^{26}$. DTL (RAMP, CDT2) is thought to play an essential role in DNA synthesis, cell cycle progression, proliferation and differentiation ${ }^{56}$. DTL controls cell cycle progression through several different mechanisms, and has an important role in the early radiation induced G2/M checkpoint ${ }^{57,58}$. The Proliferating cell nuclear antigen (PCNA)-coupled CUL4/DDB1/DTL complex can ubiquitinate and degrade key cell cycle proteins such as p53, mouse double minute 2 homolog (MDM2), p21, and E2F1 ${ }^{59-61}$. miR-502, also regulated by $\mathrm{p} 53$, acts in a feedback loop to repress expression of $\mathrm{p} 53$ indirectly ${ }^{24}$. miR-34 also acts in a feedback loop with p53 in colon cancer cells. Transfection of miR-34 into colon cancer cells leads to an increase in p53 and p21 expression as a result of down regulation of the E2F pathway ${ }^{33}$. Several other miRNAs including miR-339-5p and miR-542-3p positively regulate p53 through their targeting of p53 inhibitor MDM2 ${ }^{62,63}$. In addition to these miRNAs that regulate p53 through indirect mechanisms, others have been found to directly target p53. Among the first miRNAs found to target p53 directly, were miR-125b and
miR-504 ${ }^{64,65} \cdot$ miR-504 was demonstrated to target p53 in several cancer types, and reduce in vivo tumor growth of colon cancer cells ${ }^{65}$. In metastatic gastric cancer, miR-300 is up-regulated and acts as a tumor promoter. miR-300 was found to directly target p53 by interacting with the 3'-UTR of p53. Overexpression of miR-300 led to decreased p53 expression in gastric cancer cells, and inhibition of miR-300 led to an increase in p53 expression. Overexpression of $\mathrm{p} 53$ also reduced tumor promotion by miR-300, highlighting the importance of p53 targeting in miR-300 cellular function ${ }^{66}$. Additionally, miR-25 and miR-30d directly targeted p53 to regulate apoptosis in colon cancer cells ${ }^{67}$. These results suggest that not only can the functions of miRNAs be modulated by the p53 status in colorectal cancer, the tumor suppressive function of p53 can also be modulated by the post-transcriptional controls of various miRNAs under different stress and/or physiological conditions, providing p53 with a greater flexibility to control cell cycle and cell death.

Clearly miRNAs play important roles in the p53 regulatory network in GI cancer. p53 can regulate the transcription of several miRNAs that have important cellular functions in GI cancer. In addition, several miRNAs can regulate p53 expression to influence cellular pathways in cancer. The importance of the role of miRNAs in the p53 network is reflected in several other reviews that highlight this interaction $^{68-72}$. Our understanding of these networks will likely continue to increase as we expand our understanding of the important functions of miRNAs as well as the roles of other non-coding RNAs in p53 regulation and function. Table 2 summarizes some miRNAs that regulate p53 in GI cancers. Figure 1 depicts the involvement of miRNAs in the p53 regulatory network.

Table 2. miRNAs that regulate p53 in GI Cancer.

\begin{tabular}{|c|c|c|c|c|}
\hline miRNA & Regulation +/- & $\begin{array}{l}\text { Direct/ } \\
\text { Indirect }\end{array}$ & Function & Ref. \\
\hline miR-215 & + & Indirect & $\begin{array}{c}\uparrow / \downarrow \text { Proliferation, } \\
\uparrow / \downarrow C h e m o s e n s i t i v i t y, \\
\uparrow C \text { Cll Cycle Arrest }\end{array}$ & $25,29,42,44$ \\
\hline miR-502 & - & Indirect & $\begin{array}{c}\downarrow \text { Autophagy, } \uparrow \text { Cell Cycle } \\
\text { Arrest }\end{array}$ & 24 \\
\hline miR-34 & + & Indirect & $\begin{array}{c}\downarrow \text { Proliferation, } \uparrow \text { Cell Cycle } \\
\text { Arrest, } \uparrow \text { Apoptosis, } \\
\uparrow \text { Senescence, } \downarrow \text { Tumor } \\
\text { Sphere Formation, } \downarrow \text { EMT }\end{array}$ & $9,28,110$ \\
\hline miR-339-5p & + & Indirect & $\begin{array}{c}\uparrow \text { Cell Cycle Arrest, } \\
\uparrow \text { Senescence, } \downarrow \text { Proliferation }\end{array}$ & 62 \\
\hline miR-542-3p & + & Indirect & 个Cell Cycle Arrest & 63 \\
\hline $\operatorname{miR}-125 b$ & - & Direct & $\downarrow$ Apoptosis & 64 \\
\hline miR-504 & - & Direct & $\begin{array}{c}\downarrow \text { Apoptosis, } \downarrow \text { Cell Cycle } \\
\text { Arrest }\end{array}$ & 65 \\
\hline miR-300 & - & Direct & 个Proliferation, $\uparrow$ Migration & 66 \\
\hline $\operatorname{miR}-25$ & - & Direct & $\begin{array}{c}\downarrow \text { Apoptosis, } \downarrow \text { Cell Cycle } \\
\text { Arrest, } \downarrow \text { Senescence }\end{array}$ & 67 \\
\hline miR-30d & - & Direct & $\begin{array}{c}\downarrow \text { Apoptosis, } \downarrow \text { Cell Cycle } \\
\text { Arrest, } \downarrow \text { Senescence }\end{array}$ & 67 \\
\hline
\end{tabular}




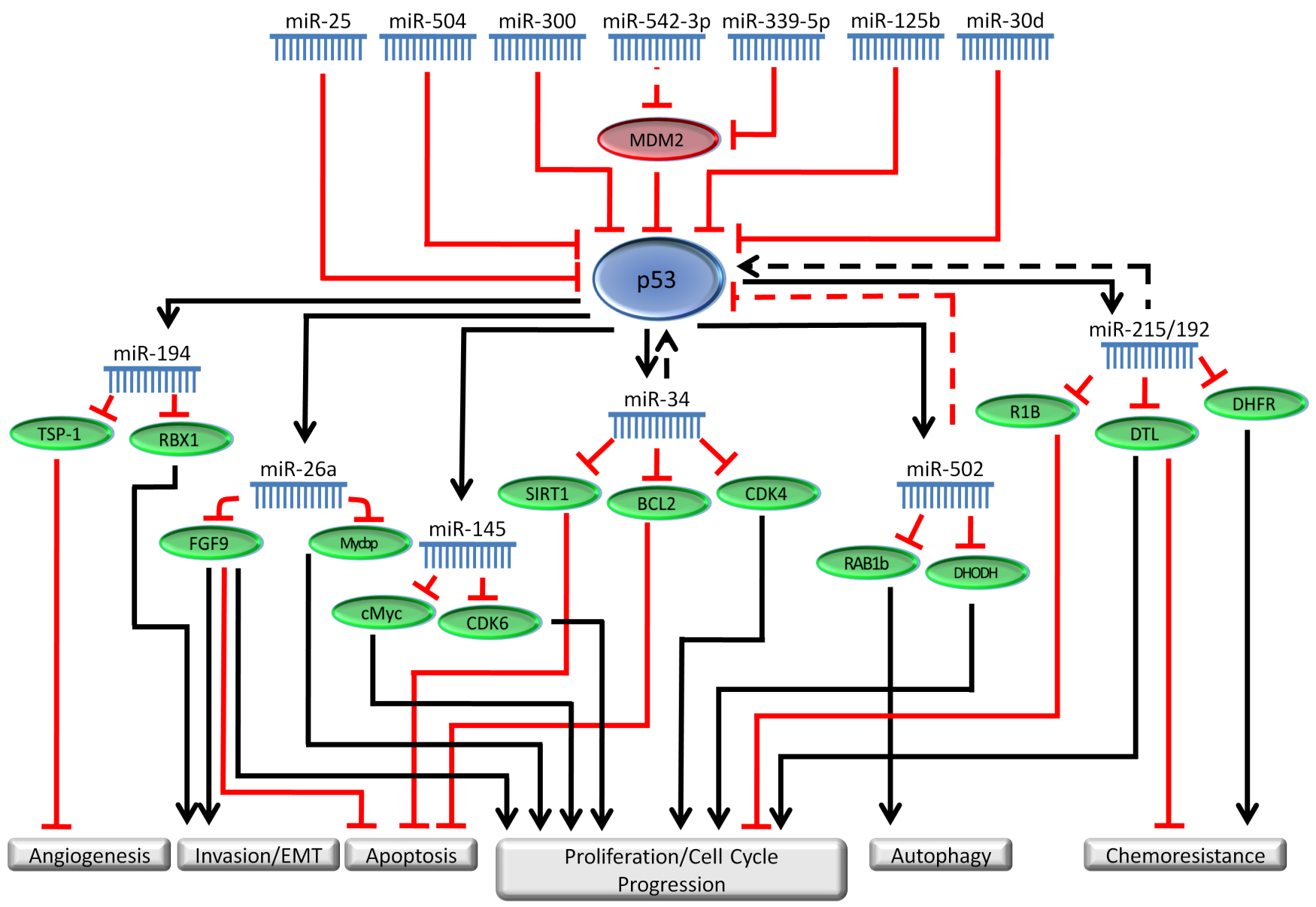

Figure 1. miRNAs have important functions in the p53 regulatory network. miRNAs regulate p53 through direct targeting as well through indirect mechanisms such as targeting p53 regulators. p53 also regulates several miRNAs, through transcriptional activation as well as other mechanisms. The miRNAs involved in the p53 network carry out important functions regulating several cellular pathways such as proliferation, apoptosis, invasion and migration. In this figure, solid lines represent direct regulation, while dashed lines represent indirect, or poorly characterized regulation.

\section{p53 and IncRNAs}

Interaction between p53 and non-coding RNA is certainly not limited to miRNA. Recent evidence has demonstrated that lncRNAs also have important functions in the p53 regulatory network. LncRNAs (200 nucleotides or more in length), thanks to improvements in sequencing technology, have begun to emerge recently as critical regulatory $\mathrm{RNAs}^{73-75}$. The understanding of the roles of lncRNAs in diseases, such as cancer, is still very limited but recent work has shown that these molecules can have some important functions in cancer biology and like miRNA are tied into the p53 regulatory network.

\section{LncRNAs regulated by $\mathrm{p} 53$}

The field of lncRNA research remains in its early stages, and we are still identifying more lncRNAs and discovering the important functions they have in the cell. The progress that has been made thus far is quite interesting and encourages increased investigation. A systematic ChIP-Seq analysis has identified 23 lncRNAs that are up-regulated by $\mathrm{p} 53^{76}$. Among the over six thousand lncRNAs that have been identified, lincRNA-p21 is one of the better characterized lncRNAs and importantly, is regulated by p53 $3^{77,78}$. LincRNA-p21 locates next to the p21 gene on mouse chromosome 17 and is activated upon DNA damaging signals in mouse cells. It has been reported that lincRNA-p21 is a direct transcriptional target of p53 and is involved in p53-dependent transcriptional responses. There is a significant overlap among the genes regulated by lincRNA-p21 expression and genes that are repressed by p53. Heterogeneous nuclear ribonucleoprotein K (hnRNP-K) plays an important role in the ability of lincRNA-p21 to regulate these genes. Expression of lincRNA-p21 in mouse embryonic fibroblasts (MEFs) also has shown the ability to induce apoptosis ${ }^{77}$. Subsequent studies further revealed that lincRNA-p21 activates p21 in cis to promote polycomb target gene expression and to enforce the G1/S checkpoint ${ }^{79}$. Recent studies also demonstrated that in human cervical carcinoma HeLa cells, a RNA binding protein, human antigen R (HuR), modulates the expression level of lincRNA-p21, 
which in turn regulates its target protein translation, such as transcription factor jun-B (JUNB) and $\beta$-catenin ${ }^{78}$. Intriguingly for this review, lincRNA-p21 can be regulated by some miRNAs including let- $7^{80}$. Our group has recently show that lincRNA-p21 is associated with colorectal cancer progression ${ }^{81}$. Such association may be due to the unique function of lincRNA-p21 under hypoxia. LincRNA-p21 is a hypoxia-responsive lncRNA and is essential for hypoxiaenhanced glycolysis ${ }^{82}$. There is a positive feedback loop between hypoxia-inducible factor 1 -alpha (HIF-1 $\alpha$ ) and lincRNA-p21 to promote tumor growth and the regulation of the Warburg effect. lincRNA-p21 has also been found to regulate the $\mathrm{Wnt} / \mathrm{\beta}$-catenin signaling pathway, and be associated with susceptibility to radiation therapy in colon cancer ${ }^{83}$. LincRNA-p21 is a powerful example of a long non-coding RNA, regulated by p53 that carries out important functions in the response pathway of p53. Another p53 regulated lncRNA named, p53 induced noncoding transcript (Pint), is a direct transcriptional target of p53. Pint is a nuclear RNA, that directly interacts with polycomb repressive complex 2 (PRC2), and is required for PRC2 targeting of specific genes for $\mathrm{H} 3 \mathrm{~K} 27$ tri-methylation and repression ${ }^{84}$. Pint is down-regulated in primary colon tumors and overexpression of Pint inhibits tumor cell proliferation, suggesting a potential tumor suppressor role ${ }^{84}$. Tumor suppressor candidate 7 (Tusc7) (LncRNA loc285194) has also been shown to be a p53 mediated tumor suppressor in colon cancer $^{85}$. Tusc 7 is transcriptionally activated by p53 to inhibit cell growth and exerts its function by suppressing miR-21 $1^{85}$. In patient samples, Tusc7 was shown to be reduced in cancer compared to normal colon tissue. Reduced Tusc7 expression is associated with increased tumor size, stage and distant metastasis as well as decreased survival ${ }^{86}$. Similar results were found in esophageal cancer as well as pancreatic cancer, suggesting Tusc 7 might be a good biomarker candidate ${ }^{87,88}$. In gastric cancer, Tusc7 expression is reduced in patient samples, and in cell lines decreases tumor cell growth. Tusc7 expression is also induced by wild type p53 but not mutant $\mathrm{p} 53^{89}$. While Tusc7 seems to act as a tumor suppressor and is reduced in several types of cancer, the picture for taurine up-regulated 1 (Tug1), another p53 regulated lncRNA, is not as clear. Tug1 was first discovered to be important in retinal development and was then shown to be a direct transcriptional target of p53 in the context of non-small cell lung cancer ${ }^{90,91}$. The role of Tug1 in cancer however, seems to be different in different cellular contexts. In lung cancer, Tug1 expression was found to be decreased in cancer tissue compared to normal. Lower expression of Tug1 correlates with higher tumor stage, increased tumor size and decreased overall survival ${ }^{91}$. In esophageal cancer however, the role of Tug 1 seems to be quite different. Tug 1 is found to be over expressed in cancer tissue with expression being correlated with tumor stage. Knockdown of Tug1 also seems to inhibit cancer cell proliferation as well as migration ${ }^{92}$. This oncogenic type function for Tug1 has also been found in bladder cancer where it appears to be up-regulated in cancer and promote cancer invasion as well as resistance to radiotherapy ${ }^{93}$. There is clearly a need to perform more research on Tug1 to get a more in-depth understanding of its functions, and confirm what has been found in these different types of cancer. The disparity seen thus far however, may be due to differences in functions of this lncRNA in different cellular contexts, something that may be expected based on what we have already discovered about the functions of miRNA in cancer. LncRNA activator of enhancer domains (LED) has recently been identified via genome-wide profiling as a p53 induced lncRNAs that acts as an enhancer to regulate $\mathrm{p} 21^{94}$. LED knockdown reduces $\mathrm{p} 21$ enhancer induction, activity, and cell cycle arrest following p53 activation. LED was identified and its function assessed in MCF-7 cells, however it has also been identified in a genome wide profile of colon cancer cells, though its specific function in this cellular context will need to be investigated ${ }^{95}$. Also identified in genome wide screening in colon cancer cells, PR-lncRNA-1 and PR-lncRNA-10 were identified as transcriptional targets of p53, that then act to regulate the transcription of target genes. These lncRNAs, may have potential tumor suppressor like function, and seem to play a role in regulating p53 anti-apoptotic and cell cycle regulatory functions. They may be important 1 cRNAs to investigate further ${ }^{96}$. Perhaps one of the more interesting p53 regulated lncRNAs is PVT1, which is transcriptionally induced by $\mathrm{p} 53$. Evidence suggests that PVT1 has an anti-apoptotic effect in colon cancer cells, and promotes proliferation and invasion ${ }^{50,97}$. PVT1 expression is also increased in colon cancer patients and increased expression predicts poor prognosis. At the same time, miR-1204 is also encoded from the PVT1 locus and seems to increase apoptosis and inhibit cell cycle progression $^{50}$. This demonstrates the complex and dynamic nature of the relationship between p53 and non-coding RNAs. LincRegulator Of Reprogramming (Linc-ROR) is a transcriptional target of p53, and inhibits p53 related apoptosis and cell cycle arrest $^{98}$. Beyond GI cancers, PANDA has been identified as a lncRNA that is a direct transcriptional target of p53. However, its function in GI cancers has not been investigated. This is something that needs to be further investigated as PANDA may have some roles in regulating apoptosis and cell cycle arrest in the p53 pathway ${ }^{99}$. Table 3 summarizes the p53 regulated lncRNAs based on their critical molecular and cellular functions in GI cancers.

\section{p53 regulation by IncRNA}

Clearly there are quite a few lncRNA that are regulated by p53 that are already known to play important roles in cancer, and undoubtedly more will be discovered in the near future. Like miRNAs however, the relationship between p53 and lncRNAs works both ways, and there have been several lncRNAs discovered to regulate p53 as well. LncRNAs can function as modulators by preventing p53 degradation. One example is human maternally expressed gene 3 (MEG3). MEG3 is a non-coding RNA that functions as a tumor suppressor in colon cancer cell lines. MEG3 down-regulates MDM2, which in turn up-regulates p53 expression level ${ }^{100}$. MEG3 can inhibit cell proliferation in the absence of p53, suggesting a possible p53 independent tumor suppressor role. LncRNAs can also inactivate p53 function and $\mathrm{H} 19$ is an example. The H19 IncRNA has been demonstrated to be associated with p53 in gastric cancer ${ }^{101}$. Such interaction resulted in partial inactivation of p53. Metastasis associated lung adenocarcinoma transcript 1 (MALAT-1) is another lncRNA that seems to regulate p53. In the case of MALAT-1, it seems to be a negative regulator of $\mathrm{p} 53$, and depletion of MALAT-1 leads to an increase in p53 expression ${ }^{102}$. In colon cancer, MALAT-1 has increased expression in cancer tissue vs. normal. Increased MALAT-1 is associated with poor patient prognosis ${ }^{103}$. In colon cancer cell lines, overexpression of MALAT-1 promotes proliferation, migration and invasion. These functions are associated with regulation of A-kinase anchor protein 9 (AKAP-9) by MALAT- ${ }^{104}$. LincRNA-ROR acting in a feedback loop, is also able to regulate p53, and knockdown of 
lincRNA-ROR leads to an increase in genes in the p53 pathway response ${ }^{98,105}$. There is also recent evidence that lincRNA-ROR expression is reduced in colon cancer, however more needs to be done to investigate this role ${ }^{106}$. Table 4 summarizes lncRNAs that regulate $\mathrm{p} 53$ in GI cancers. Through their regulation by $\mathrm{p} 53$ or their ability to regulate $\mathrm{p} 53$, IncRNAs clearly have important functions in the p53 network, and our appreciation of these roles will continue to grow as we discover additional lncRNAs and elucidate their functions in cancer. Figure 2 depicts lncRNAs' roles in the p53 regulatory network.

\section{Summary}

The research community continues to push the boundaries of the p53 regulatory networks beyond protein coding genes to noncoding RNAs and other novel entities. There are many circular RNAs that have been discovered recently ${ }^{107,108}$. The impact of

Table 3. p53 Regulated IncRNA in GI Cancer.

\begin{tabular}{|c|c|c|c|c|}
\hline IncRNA & $\begin{array}{c}\text { Transcriptional } \\
\text { Target }\end{array}$ & $\begin{array}{c}\text { Tumor Suppressor/ } \\
\text { Oncogene }\end{array}$ & Function & Ref. \\
\hline lincRNA-p21 & Yes & * & $\begin{array}{c}\text { 个Apoptosis, } \uparrow \text { Cell } \\
\text { Cycle Arrest, } \\
\text { 个Radiation } \\
\text { Sensitivity, } \\
\text { 个Hypoxia Resistance }\end{array}$ & $77,79,81-83$ \\
\hline Pint & Yes & Tumor Suppressor & $\begin{array}{l}\uparrow \text { Apoptosis, } \\
\downarrow \text { Proliferation }\end{array}$ & 84 \\
\hline Tusc7 & Yes & Tumor Suppressor & $\downarrow$ Proliferation, & $85-89$ \\
\hline Tug1 & Yes & * & 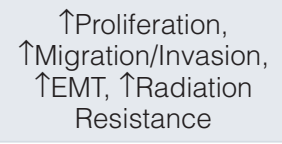 & $91-93$ \\
\hline LED & Yes & * & Cell Cycle Arrest & 94,95 \\
\hline PR-IncRNA-1 & Yes & Tumor Suppressor & $\begin{array}{l}\uparrow \text { Apoptosis, } \\
\downarrow \text { Proliferation }\end{array}$ & 96 \\
\hline PR-IncRNA-10 & Yes & Tumor Suppressor & $\begin{array}{l}\uparrow \text { Apoptosis, } \\
\downarrow \text { Proliferation }\end{array}$ & 96 \\
\hline PVT1 & Yes & * & $\begin{array}{l}\uparrow \text { Proliferation } \\
\downarrow \text { Apoptosis }\end{array}$ & 50,97 \\
\hline LincRNA-ROR & Yes & * & $\begin{array}{c}\downarrow \text { Apoptosis, } \\
\downarrow \text { Cell Cycle Arrest }\end{array}$ & $98,105,106$ \\
\hline
\end{tabular}

*--Role not clear, or conflicting reports in different cancer types

Table 4. IncRNA that regulate p53 in GI Cancer.

\begin{tabular}{|c|c|c|c|c|}
\hline IncRNA & Regulation +/- & $\begin{array}{c}\text { Tumor Suppressor/ } \\
\text { Oncogene }\end{array}$ & Function & Ref. \\
\hline MEG3 & + & Tumor Suppressor & $\downarrow$ Proliferation & 100 \\
\hline $\mathrm{H} 19$ & - & Oncogene & $\begin{array}{c}\text { } \text { Proliferation, } \\
\downarrow \text { Apoptosis }\end{array}$ & 101 \\
\hline MALAT-1 & - & Oncogene & $\begin{array}{c}\uparrow \text { Cell Cycle } \\
\text { Progression, } \\
\uparrow \text { Migration/Invasion }\end{array}$ & $102-104$ \\
\hline LincRNA-ROR & - & * & $\begin{array}{c}\downarrow \text { Apoptosis, } \\
\downarrow \text { Cell Cycle Arrest }\end{array}$ & $98,105,106$ \\
\hline
\end{tabular}

*--Role not clear, or conflicting reports in different cancer types 


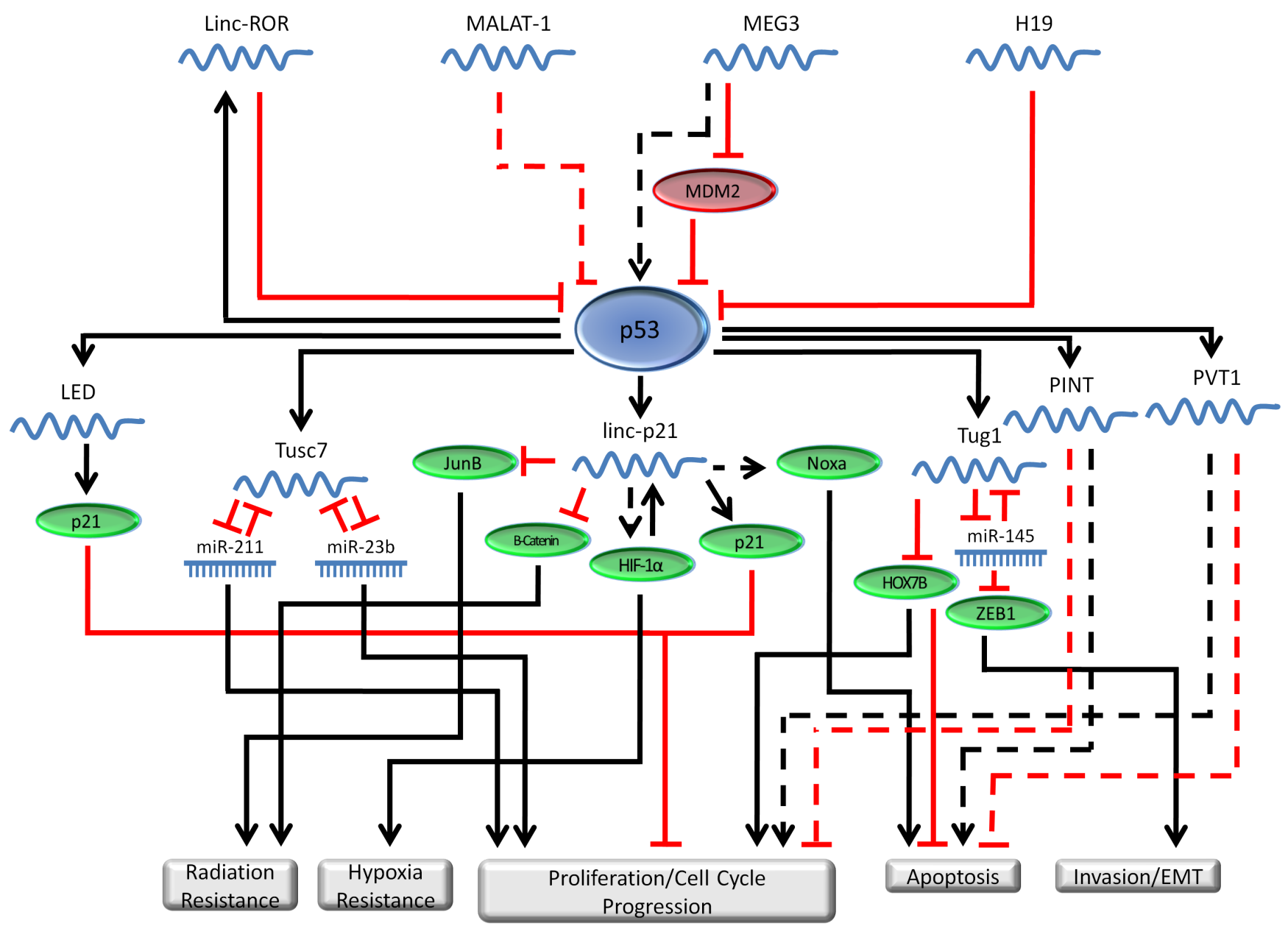

Figure 2. IncRNA have important functions in the p53 regulatory network. IncRNAs, have a function in regulating p53. p53 in turn regulates the expression of several different IncRNAs. The IncRNAs involved in the p53 network regulate cellular functions such as proliferation, apoptosis, invasion and migration. In this figure, solid lines represent direct regulation, while dashed lines represent indirect, or poorly characterized regulation.

p53 on circular RNAs in GI cancer will potentially be an important field to explore going forward. As protein coding genes only represent a small percentage of our genome, we can expect more exciting discoveries in the non-coding RNA field impacted by 553. We hope that with the advancement of high throughput genomics technology and computational biology approaches, we can fully access the complete spectrum and scope of the p53 regulatory network. Such insight will provide a foundation to study other key proteins in cancer and other diseases. It will also help us to develop novel therapeutic strategies to combat cancer ${ }^{109}$.

Author contributions

Andrew Fesler, Ning Zhang and Jingfang Ju wrote the manuscript.
Competing interests

No competing interests were disclosed.

\section{Grant information}

This study was supported by National Institute of Health/National Cancer Institute R01CA155019 (J. Ju), R33CA147966 (J. Ju).

The funders had no role in study design, data collection and analysis, decision to publish, or preparation of the manuscript.

\section{Acknowledgements}

We apologize to our colleagues whose research was not cited in this review due to space limitations and timing. 
1. Kress M, May E, Cassingena R, et al:: Simian virus 40-transformed cells express new species of proteins precipitable by anti-simian virus $\mathbf{4 0}$ tumor serum. $J$ Virol. 1979; 31(2): 472-483.

PubMed Abstract | Free Full Text

2. Lane DP, Crawford LV: T antigen is bound to a host protein in SV40-transformed cells. Nature. 1979; 278(5701): 261-263.

PubMed Abstract | Publisher Full Text

3. Linzer DI, Levine AJ: Characterization of a $\mathbf{5 4 K}$ dalton cellular SV40 tumor antigen present in SV40-transformed cells and uninfected embryonal carcinoma cells. Cell. 1979; 17(1): 43-52.

PubMed Abstract | Publisher Full Text

4. Vogelstein B, Kinzler KW: p53 function and dysfunction. Cell. 1992; 70(4): 523-526. PubMed Abstract | Publisher Full Text

5. Riley $\mathrm{T}$, Sontag $\mathrm{E}$, Chen $\mathrm{P}$, et al.: Transcriptional control of human p53-regulated genes. Nat Rev Mol Cell Biol. 2008; 9(5): 402-412.

PubMed Abstract | Publisher Full Text

6. Vaseva AV, Moll UM: The mitochondrial p53 pathway. Biochim Biophys Acta. 2009; 1787(5): 414-420.

PubMed Abstract | Publisher Full Text | Free Full Text

7. Mosner J, Mummenbrauer T, Bauer C, et al:: Negative feedback regulation of wild-type p53 biosynthesis. EMBO J. 1995; 14(18): 4442-4449. PubMed Abstract | Free Full Text

8. $\mathrm{Xi}$ Y, Shalgi R, Fodstad $\mathrm{O}$, et al.: Differentially regulated micro-RNAs and actively translated messenger RNA transcripts by tumor suppressor p53 in colon cancer. Clin Cancer Res. 2006; 12 (7 Pt 1): 2014-2024. PubMed Abstract | Publisher Full Text

9. Raver-Shapira N, Marciano E, Meiri E, et al:: Transcriptional activation of miR-34a contributes to p53-mediated apoptosis. Mol Cell. 2007; 26(5): 731-743. PubMed Abstract | Publisher Full Text

10. Ju J, Pedersen-Lane J, Maley F, et al:: Regulation of p53 expression by thymidylate synthase. Proc Natl Acad Sci U S A. 1999; 96(7): 3769-3774. PubMed Abstract | Publisher Full Text | Free Full Text

11. Chu E, Copur SM, Ju J, et al:: Thymidylate synthase protein and p53 mRNA form an in vivo ribonucleoprotein complex. Mol Cell Biol. 1999; 19(2): 1582-1594. PubMed Abstract | Publisher Full Text | Free Full Text

12. Garofalo $\mathrm{M}$, Croce $\mathrm{CM}$ : MicroRNAs as therapeutic targets in chemoresistance. Drug Resist Updat. 2013; 16(3-5): 47-59.

PubMed Abstract | Publisher Full Text | Free Full Text

13. Mattick JS: The genetic signatures of noncoding RNAs. PLoS Genet. 2009; 5(4) e1000459.

PubMed Abstract | Publisher Full Text | Free Full Text

14. Wahlestedt $\mathrm{C}$ : Targeting long non-coding RNA to therapeutically upregulate gene expression. Nat Rev Drug Discov. 2013; 12(6): 433-446. gene expression. Nat Rev Drug Discov.

15. Gutschner T, Diederichs S: The hallmarks of cancer: a long non-coding RNA point of view. RNA Biol. 2012; 9(6): 703-719. PubMed Abstract | Publisher Full Text | Free Full Text

16. Scott N, Sagar P, Stewart J, et al.: p53 in colorectal cancer: clinicopathological correlation and prognostic significance. Br J Cancer. 1991; 63(2): 317-319. PubMed Abstract | Publisher Full Text | Free Full Text

17. Crawford LV, Pim DC, Lamb P: The cellular protein $\mathrm{p} 53$ in human tumours. $\mathrm{Mol}$ Biol Med. 1984; 2(4): 261-272. PubMed Abstract

18. Vogelstein B, Fearon ER, Hamilton SR, et al:: Genetic alterations during colorectal-tumor development. N Engl J Med. 1988; 319(9): 525-532. PubMed Abstract | Publisher Full Text

19. Zhao R, Gish K, Murphy M, et al.: Analysis of p53-regulated gene expression patterns using oligonucleotide arrays. Genes Dev. 2000; 14(8): 981-993. PubMed Abstract | Free Full Text

20. Miller SJ, Suthiphongchai T, Zambetti GP, et al:: p53 binds selectively to the 5 ' untranslated region of $c d k 4$, an RNA element necessary and sufficient fo transforming growth factor beta- and p53-mediated translational inhibition of cdk4. Mol Cell Biol. 2000; 20(22): 8420-8431. PubMed Abstract | Publisher Full Text | Free Full Text

21. Fu L, Minden MD, Benchimol S: Translational regulation of human p53 gene expression. EMBO J. 1996; 15(16): 4392-4401.

PubMed Abstract | Free Full Text

22. Bartel DP: MicroRNAs: genomics, biogenesis, mechanism, and function. Cell. 2004; 116(2): 281-297. PubMed Abstract | Publisher Full Text

23. Friedman RC, Farh $\mathrm{KK}$, Burge $\mathrm{CB}$, et al:: Most mammalian mRNAs are conserved targets of microRNAs. Genome Res. 2009; 19(1): 92-105. PubMed Abstract | Publisher Full Text | Free Full Text

24. Zhai H, Song $\mathrm{B}, \mathrm{Xu} \mathrm{X}$, et al:: Inhibition of autophagy and tumor growth in colon cancer by miR-502. Oncogene. 2013; 32(12): 1570-9. PubMed Abstract | Publisher Full Text | Free Full Text

25. Song B, Wang $\mathrm{Y}$, Kudo K, et al.: $\mathbf{m i R}$-192 Regulates dihydrofolate reductase and cellular proliferation through the p53-microRNA circuit. Clin Cancer Res. 2008;
14(24): 8080-8086.

PubMed Abstract | Publisher Full Text | Free Full Text

26. Song B, Wang Y, Titmus MA, et al.: Molecular mechanism of chemoresistance by miR-215 in osteosarcoma and colon cancer cells. Mol Cancer. 2010; 9: 96. PubMed Abstract | Publisher Full Text | Free Full Text

27. Song $B$, Wang $Y, X i Y$, et al:: Mechanism of chemoresistance mediated by miR-140 in human osteosarcoma and colon cancer cells. Oncogene. 2009; 28(46): 4065-4074.

PubMed Abstract | Publisher Full Text | Free Full Text

28. Chang TC, Wentzel EA, Kent OA, et al:: Transactivation of miR-34a by p53 broadly influences gene expression and promotes apoptosis. Mol Cell. 2007; 26(5): 745-752.

PubMed Abstract | Publisher Full Text | Free Full Text

29. Braun CJ, Zhang X, Savelyeva I, et al.: p53-Responsive micrornas 192 and 215 are capable of inducing cell cycle arrest. Cancer Res. 2008; 68(24): 10094-10104. PubMed Abstract | Publisher Full Text | Free Full Text

30. Gregory PA, Bert AG, Paterson EL, et al:: The miR-200 family and miR-205 regulate epithelial to mesenchymal transition by targeting ZEB1 and SIP1. Nat Cell Biol. 2008; 10(5): 593-601.

PubMed Abstract | Publisher Full Text

31. Zeitels LR, Acharya A, Shi G, et al:: Tumor suppression by miR-26 overrides potential oncogenic activity in intestinal tumorigenesis. Genes Dev. 2014; 28(23): 2585-2590.

PubMed Abstract | Publisher Full Text | Free Full Text

32. Deng $M$, Tang HL, Lu XH, et al:: miR-26a suppresses tumor growth and metastasis by targeting FGF9 in gastric cancer. PLoS One. 2013; 8(8): e72662. PubMed Abstract | Publisher Full Text | Free Full Text

33. Tazawa $\mathrm{H}$, Tsuchiya $\mathrm{N}$, Izumiya $\mathrm{M}$, et al:: Tumor-suppressive $\boldsymbol{m i R}$-34a induces senescence-like growth arrest through modulation of the E2F pathway in human colon cancer cells. Proc Natl Acad Sci U S A. 2007; 104(39): 15472-15477. PubMed Abstract | Publisher Full Text | Free Full Text

34. He L, He X, Lim LP, et al:: A microRNA component of the p53 tumour suppressor network. Nature. 2007; 447(7148): 1130-1134.

PubMed Abstract | Publisher Full Text | Free Full Text

35. Yamakuchi M, Ferlito M, Lowenstein CJ: miR-34a repression of SIRT1 regulates apoptosis. Proc Natl Acad Sci U S A. 2008; 105(36): 13421-13426. PubMed Abstract | Publisher Full Text | Free Full Text

36. Rokavec M, Öner MG, Li H, et al:: IL-6R/STAT3/miR-34a feedback loop promotes EMT-mediated colorectal cancer invasion and metastasis. J Clin Invest. 2014; 124(4): 1853-1867.

PubMed Abstract | Publisher Full Text | Free Full Text

37. Hermeking H: The miR-34 family in cancer and apoptosis. Cell Death Differ. 2010; 17(2): 193-199.

PubMed Abstract | Publisher Full Text

38. Ji Q, Hao X, Meng Y, et al:: Restoration of tumor suppressor miR-34 inhibits human p53-mutant gastric cancer tumorspheres. BMC Cancer. 2008; 8: 266 PubMed Abstract | Publisher Full Text | Free Full Text

39. Bader AG: miR-34 - a microRNA replacement therapy is headed to the clinic. Front Genet. 2012; 3: 120.

PubMed Abstract | Publisher Full Text | Free Full Text

40. Georges SA, Biery MC, Kim SY, et al:: Coordinated regulation of cell cycle transcripts by p53-Inducible microRNAs, miR-192 and miR-215. Cancer Res. 2008; 68(24): 10105-10112.

PubMed Abstract | Publisher Full Text

41. Karaayvaz M, Pal T, Song B, et al:: Prognostic significance of miR-215 in colon cancer. Clin Colorectal Cancer. 2011: 10(4): 340-7.

PubMed Abstract | Publisher Full Text | Free Full Text

42. Boni V, Bitarte N, Cristobal I, et al:: miR-192/miR-215 influence 5-fluorouracil resistance through cell cycle-mediated mechanisms complementary to its post-transcriptional thymidilate synthase regulation. Mol Cancer Ther. 2010; 9(8): 2265-2275.

PubMed Abstract | Publisher Full Text

43. Deng $Y$, Huang $Z, X u Y$, et al:: MiR-215 modulates gastric cancer cell proliferation by targeting RB1. Cancer Lett. 2014; 342(1): 27-35. PubMed Abstract | Publisher Full Text

44. Xu YJ, Fan Y: MiR-215/192 participates in gastric cancer progression. Clin Transl Oncol. 2015; 17(1): 34-40. PubMed Abstract | Publisher Full Text

45. Bansal A, Hong X, Lee IH, et al:: MicroRNA Expression can be a Promising Strategy for the Detection of Barrett's Esophagus: A Pilot Study. Clin Trans Gastroenterol. 2014; 5(12): e65. PublMed Abstract | Publisher Full Text | Free Full Text

46. Sundaram P, Hultine S, Smith LM, et al.: p53-responsive miR-194 inhibits thrombospondin-1 and promotes angiogenesis in colon cancers. Cancer Res. 2011; 71(24): 7490-7501.

PubMed Abstract | Publisher Full Text | Free Full Text

47. Chen X, Wang Y, Zang W, et al.: miR-194 targets RBX1 gene to modulate proliferation and migration of gastric cancer cells. Tumour Biol. 2015; 36(4) 
2393-2401.

PubMed Abstract | Publisher Full Text

48. Sachdeva M, Zhu S, Wu F, et al.: p53 represses c-Myc through induction of the tumor suppressor miR-145. Proc Natl Acad Sci U S A. 2009; 106(9): 3207-3212. PubMed Abstract | Publisher Full Text | Free Full Text

49. Suzuki HI, Yamagata K, Sugimoto $\mathrm{K}$, et al:: Modulation of microRNA processing by p53. Nature. 2009; 460(7254): 529-33. PubMed Abstract | Publisher Full Text

50. Barsotti AM, Beckerman R, Laptenko O, et al:: p53-Dependent induction of PVT1 and miR-1204. J Biol Chem. 2012; 287(4): 2509-2519. PubMed Abstract | Publisher Full Text | Free Full Text

51. Dittmer D, Pati S, Zambetti G, et al.: Gain of function mutations in p53. Nat Genet. 1993; 4(1): 42-46.

PubMed Abstract | Publisher Full Text

52. Blandino G, Levine AJ, Oren M: Mutant p53 gain of function: differential effects of different p53 mutants on resistance of cultured cells to chemotherapy. Oncogene. 1999; 18(2): 477-485. PubMed Abstract

53. Dong $\mathrm{P}$, Karaayvaz M, Jia N, et al:: Mutant p53 gain-of-function induces epithelial-mesenchymal transition through modulation of the miR-130b-ZEB1 axis. Oncogene. 2013; 32(27): 3286-3295. PubMed Abstract | Publisher Full Text | Free Full Text

54. Subramanian M, Francis $\mathrm{P}$, Bilke $\mathrm{S}$, et al.: A mutant p53/let-7i-axis-regulated gene network drives cell migration, invasion and metastasis. Oncogene. 2015; 34(9): 1094-1104.

PubMed Abstract | Publisher Full Text | Free Full Text

55. Masciarelli S, Fontemaggi G, Di Agostino S, et al.: Gain-of-function mutant p53 downregulates miR-223 contributing to chemoresistance of cultured tumor cells. Oncogene. 2014; 33(12): 1601-1608. PubMed Abstract | Publisher Full Text

56. Pan HW, Chou HY, Liu SH, et al:: Role of L2DTL, cell cycle-regulated nuclear and centrosome protein, in aggressive hepatocellular carcinoma. Cell cycle. 2006; 5(22): 2676-2687.

PubMed Abstract | Publisher Full Text

57. Higa LA, Banks D, Wu M, et al.: L2DTL/CDT2 interacts with the CUL4/DDB1 complex and PCNA and regulates CDT1 proteolysis in response to DNA damage. Cell cycle. 2006; 5(15): 1675-1680. PubMed Abstract | Publisher Full Text

58. Sansam CL, Shepard JL, Lai K, et al.: DTL/CDT2 is essential for both CDT1 regulation and the early G2/M checkpoint. Genes Dev. 2006; 20(22): 3117-3129. PubMed Abstract | Publisher Full Text | Free Full Text

59. Banks D, Wu M, Higa LA, et al.: L2DTL/CDT2 and PCNA interact with p53 and regulate $p 53$ polyubiquitination and protein stability through MDM2 and CUL4A/DDB1 complexes. Cell cycle. 2006; 5(15): 1719-1729. PubMed Abstract | Publisher Full Text

60. Nishitani $\mathrm{H}$, Shiomi $\mathrm{Y}$, lida $\mathrm{H}$, et al.: CDK inhibitor $\mathrm{p} 21$ is degraded by a proliferating cell nuclear antigen-coupled Cul4-DDB1 ${ }^{\text {cdt2 }}$ pathway during S phase and after UV irradiation. J Biol Chem. 2008; 283(43): 29045-29052. PubMed Abstract | Publisher Full Text | Free Full Text

61. Shibutani ST, de la Cruz AF, Tran V, et al:: Intrinsic negative cell cycle regulation provided by PIP box- and Cul4 $4^{\text {cdt2 }}$-mediated destruction of E2f1 during $S$ phase. Dev Cell. 2008; 15(6): 890-900

PubMed Abstract | Publisher Full Text | Free Full Text

62. Jansson MD, Damas ND, Lees M, et al.: miR-339-5p regulates the p53 tumorsuppressor pathway by targeting MDM2. Oncogene. 2015; 34(15): 1908-1918. PubMed Abstract | Publisher Full Text

63. Wang $\mathrm{Y}$, Huang JW, Castella $\mathrm{M}$, et al:: $\mathrm{p} 53$ is positively regulated by miR-542-3p. Cancer Res. 2014; 74(12): 3218-3227.

PubMed Abstract | Publisher Full Text | Free Full Text

64. Le MT, Teh C, Shyh-Chang N, et al:: MicroRNA-125b is a novel negative regulator of p53. Genes Dev. 2009; 23(7): 862-876. PubMed Abstract | Publisher Full Text | Free Full Text

65. Hu W, Chan CS, Wu R, et al.: Negative regulation of tumor suppressor p53 by microRNA miR-504. Mol Cell. 2010; 38(5): 689-699.

PubMed Abstract | Publisher Full Text | Free Full Text

66. Shen Z, Li C, Zhang K, et al.: The up-regulation of miR-300 in gastric cancer and its effects on cells malignancy. Int J Clin Exp Med. 2015; 8(5): 6773-6783. PubMed Abstract | Free Full Text

67. Kumar M, Lu Z, Takwi AA, et al:: Negative regulation of the tumor suppressor p53 gene by microRNAs. Oncogene. 2011; 30(7): 843-853. PubMed Abstract | Publisher Full Text | Free Full Text

68. Otsuka K, Ochiya T: Genetic networks lead and follow tumor development: microRNA regulation of cell cycle and apoptosis in the p53 pathways. Biomed Res Int. 2014; 2014: 749724.

PubMed Abstract | Publisher Full Text | Free Full Text

69. Rokavec $\mathrm{M}$, Li H, Jiang L, et al.: The p53/microRNA connection in gastrointestinal cancer. Clin Exp Gastroenterol. 2014; 7: 395-413. PubMed Abstract | Publisher Full Text | Free Full Text

70. Hoffman Y, Pilpel Y, Oren M: microRNAs and Alu elements in the p53-Mdm2Mdm4 regulatory network. J Mol Cell Biol. 2014; 6(3): 192-197. PubMed Abstract | Publisher Full Text | Free Full Text

71. Liao JM, Cao B, Zhou X, et al:: New insights into $p 53$ functions through its target microRNAs. J Mol Cell Biol. 2014; 6(3): 206-213

PubMed Abstract | Publisher Full Text | Free Full Text

72. Li XL, Jones MF, Subramanian M, et al.: Mutant p53 exerts oncogenic effects through microRNAs and their target gene networks. FEBS Lett. 2014; 588(16): 2610-2615.

PubMed Abstract | Publisher Full Text

73. Mercer TR, Dinger ME, Mattick JS: Long non-coding RNAs: insights into functions. Nat Rev Genet. 2009; 10(3): 155-159.

PubMed Abstract | Publisher Full Text

74. Ponting CP, Oliver PL, Reik W: Evolution and functions of long noncoding RNAs. Cell. 2009; 136(4): 629-641. PubMed Abstract | Publisher Full Text

75. Ponjavic J, Ponting CP, Lunter G: Functionality or transcriptional noise? Evidence for selection within long noncoding RNAs. Genome Res. 2007; 17(5): 556-565. PubMed Abstract | Publisher Full Text | Free Full Text

76. Idogawa M, Ohashi T, Sasaki $\mathrm{Y}$, et al.: Identification and analysis of large intergenic non-coding RNAs regulated by p 53 family members through a genome-wide analysis of p53-binding sites. Hum Mol Genet. 2014; 23(11): 2847-2857.

PubMed Abstract | Publisher Full Text

77. Huarte $M$, Guttman $M$, Feldser $D$, et al:: A large intergenic noncoding RNA induced by $\mathrm{p} 53$ mediates global gene repression in the $\mathrm{p} 53$ response. Cell. 2010; 142(3): 409-419.

PubMed Abstract | Publisher Full Text | Free Full Text

78. Yoon JH, Abdelmohsen $\mathrm{K}$, Srikantan $\mathrm{S}$, et al.: LincRNA-p21 suppresses target mRNA translation. Mol Cell. 2012; 47(4): 648-655. PubMed Abstract | Publisher Full Text | Free Full Text

79. Dimitrova N, Zamudio JR, Jong RM, et al:: LincRNA-p21 activates p21 in cis to promote Polycomb target gene expression and to enforce the G1/S checkpoint. Mol Cell. 2014; 54(5): 777-790.

PubMed Abstract | Publisher Full Text | Free Full Text

80. Yoon JH, Srikantan S, Gorospe M: MS2-TRAP (MS2-tagged RNA affinity purification): tagging RNA to identify associated miRNAs. Methods. 2012; 58(2): 81-87.

PubMed Abstract | Publisher Full Text | Free Full Text

81. Zhai H, Fesler A, Schee $\mathrm{K}$, et al:: Clinical significance of long intergenic noncoding RNA-p21 in colorectal cancer. Clin Colorectal Cancer. 2013; 12(4): 261-266.

PubMed Abstract | Publisher Full Text

82. Yang $\mathrm{F}$, Zhang $\mathrm{H}$, Mei $\mathrm{Y}$, et al.: Reciprocal regulation of HIF-1 $\alpha$ and lincRNA-p21 modulates the Warburg effect. Mol Cell. 2014; 53(1): 88-100. PubMed Abstract | Publisher Full Text

83. Wang G, Li Z, Zhao Q, et al:: LincRNA-p21 enhances the sensitivity of radiotherapy for human colorectal cancer by targeting the Wnt/3-catenin signaling pathway. Oncol Rep. 2014; 31(4): 1839-1845. PubMed Abstract | Publisher Full Text

84. Marín-Béjar O, Marchese FP, Athie A, et al:: Pint lincRNA connects the p53 pathway with epigenetic silencing by the Polycomb repressive complex 2 . Genome Biol. 2013; 14(9): R104.

PubMed Abstract | Publisher Full Text | Free Full Text

85. Liu Q, Huang J, Zhou N, et al.: LncRNA loc285194 is a p53-regulated tumor suppressor. Nucleic Acids Res. 2013; 41(9): 4976-4987. PubMed Abstract| Publisher Full Text |Free Full Text

86. Qi P, Xu MD, Ni SJ, et al.: Low expression of LOC285194 is associated with poor prognosis in colorectal cancer. J Transl Med. 2013; 11: 122. PubMled Abstract | Publisher Full Text | Free Full Text

87. Tong YS, Zhou XL, Wang XW, et al:: Association of decreased expression of long non-coding RNA LOC285194 with chemoradiotherapy resistance and poor prognosis in esophageal squamous cell carcinoma. J Transl Med. 2014; 12: 233.

PubMed Abstract | Publisher Full Text | Free Full Text

88. Ding YC, Yu W, Ma C, et al.: Expression of long non-coding RNA LOC285194 and its prognostic significance in human pancreatic ductal adenocarcinoma. Int J Clin Exp Pathol. 2014; 7(11): 8065-8070. PubMed Abstract | Free Full Text

89. Qi P, Xu MD, Shen XH, et al:: Reciprocal repression between TUSC7 and miR-23b in gastric cancer. Int J Cancer. 2015; 137(6): 1269-1278. PubMed Abstract | Publisher Full Text

90. Young TL, Matsuda T, Cepko CL: The noncoding RNA taurine upregulated gene is required for differentiation of the murine retina. Curr Biol. 2005; 15(6): $501-512$.

PubMed Abstract | Publisher Full Text

91. Zhang EB, Yin DD, Sun M, et al:: P53-regulated long non-coding RNA TUG1 affects cell proliferation in human non-small cell lung cancer, partly through epigenetically regulating HOXB7 expression. Cell Death Dis. 2014; 5(5): e1243. PubMed Abstract | Publisher Full Text | Free Full Text

92. Xu Y, Wang J, Qu M, et al:: Upregulation of the long noncoding RNA TUG1 promotes proliferation and migration of esophageal squamous cell carcinoma. Tumour Biol. 2015; 36(3): 1643-1651. PubMed Abstract | Publisher Full Text

93. Tan J, Qiu K, Li M, et al.: Double-negative feedback loop between long non-coding RNA TUG1 and miR-145 promotes epithelial to mesenchymal 
transition and radioresistance in human bladder cancer cells. FEBS Lett. 2015; 589(20 Pt B): 3175-81.

PubMed Abstract | Publisher Full Text

94. Léveillé N, Melo CA, Rooijers K, et al:: Genome-wide profiling of p53-regulated enhancer RNAs uncovers a subset of enhancers controlled by a IncRNA. Nat Commun. 2015; 6: 6520

PubMed Abstract | Publisher Full Text | Free Full Text

95. Allen MA, Andrysik Z, Dengler VL, et al:: Global analysis of p53-regulated transcription identifies its direct targets and unexpected regulatory mechanisms. elife. 2014; 3: e02200.

PubMed Abstract | Publisher Full Text | Free Full Text

96. Sánchez Y, Segura V, Marín-Béjar O, et al:: Genome-wide analysis of the human p53 transcriptional network unveils a IncRNA tumour suppressor signature. Nat Commun. 2014; 5: 5812

PubMed Abstract | Publisher Full Text | Free Full Text

97. Takahashi Y, Sawada G, Kurashige J, et al: Amplification of PVT-1 is involved in poor prognosis via apoptosis inhibition in colorectal cancers. Br J Cancer. 2014; 110(1): 164-171.

PubMed Abstract | Publisher Full Text | Free Full Text

98. Zhang A, Zhou N, Huang J, et al:: The human long non-coding RNA-RoR is a p53 repressor in response to DNA damage. Cell Res. 2013; 23(3): 340-350. PubMed Abstract | Publisher Full Text | Free Full Text

99. Hung $\mathrm{T}$, Wang $\mathrm{Y}$, Lin MF, et al:: Extensive and coordinated transcription of noncoding RNAs within cell-cycle promoters. Nat Genet. 2011; 43(7): 621-629.

PubMed Abstract | Publisher Full Text | Free Full Text

100. Zhou $Y$, Zhong $Y$, Wang $Y$, et al:: Activation of p53 by MEG3 non-coding RNA. J Biol Chem. 2007; 282(34): 24731-24742. PubMed Abstract | Publisher Full Text

101. Yang $\mathrm{F}, \mathrm{Bi} \mathrm{J}$, Xue X, et al.: Up-regulated long non-coding RNA H19 contributes to proliferation of gastric cancer cells. FEBS J. 2012; 279(17): 3159-3165. PubMed Abstract | Publisher Full Text
102. Tripathi $V$, Shen $Z$, Chakraborty A, et al.: Long noncoding RNA MALAT1 controls cell cycle progression by regulating the expression of oncogenic transcription factor B-MYB. PLoS Genet. 2013; 9(3): e1003368. PubMed Abstract | Publisher Full Text | Free Full Text

103. Zheng HT, Shi DB, Wang YW, et al:: High expression of IncRNA MALAT1 suggests a biomarker of poor prognosis in colorectal cancer. Int J Clin Exp Pathol. 2014; 7(6): 3174-3181. PubMed Abstract | Free Full Text

104. Yang MH, Hu ZY, Xu C, et al:: MALAT1 promotes colorectal cancer cell proliferation/migration/invasion via PRKA kinase anchor protein 9. Biochim Biophys Acta. 2015; 1852(1): 166-174.

PubMed Abstract | Publisher Full Text | Free Full Text

105. Loewer S, Cabili MN, Guttman M, et al.: Large intergenic non-coding RNA-RoR modulates reprogramming of human induced pluripotent stem cells. Nat Genet. 2010; 42(12): 1113-1117.

PubMed Abstract | Publisher Full Text | Free Full Tex

106. Rezaei M, Emadi-Baygi M, Hoffmann MJ, et al:: Altered expression of LINC-ROR in cancer cell lines and tissues. Tumour Biol. 2015; 1-7. PubMed Abstract | Publisher Full Text

107. Guo JU, Agarwal V, Guo H, et al.: Expanded identification and characterization of mammalian circular RNAs. Genome Biol. 2014; 15(7): 409. PubMed Abstract | Publisher Full Text | Free Full Text

108. Jeck WR, Sharpless NE: Detecting and characterizing circular RNAs. Nat Biotechnol. 2014; 32(5): 453-461. PubMed Abstract | Publisher Full Text | Free Full Text

109. Ju J, Jiang J, Fesler A: miRNA: the new frontier in cancer medicine. Future Med Chem. 2013; 5(9): 983-985.

PubMed Abstract | Publisher Full Text | Free Full Text

110. Tarasov $V$, Jung $P$, Verdoodt $B$, et al: Differential regulation of microRNAs by p53 revealed by massively parallel sequencing: $\mathrm{miR}-34 \mathrm{a}$ is a p53 target that induces apoptosis and G1-arrest. Cell cycle. 2007; 6(13): 1586-1593. PubMed Abstract | Publisher Full Tex 


\section{Open Peer Review}

\section{Current Peer Review Status:}

\section{Version 1}

Reviewer Report 07 June 2016

https://doi.org/10.5256/f1000research.8996.r14211

(C) 2016 Samant $\mathbf{R}$. This is an open access peer review report distributed under the terms of the Creative Commons Attribution License, which permits unrestricted use, distribution, and reproduction in any medium, provided the original work is properly cited.

\section{Rajeev S. Samant}

Department of Pathology, University of Alabama at Birmingham, Birmingham, AL, USA

This article by Fesler et al. is a timely summary of the state of the art of P53 related regulatory mechanisms with specific emphasis on colon cancer. P53 is certainly the most critical node of oncogenesis and progression. With the rapidly advancing information about the importance of non-coding RNA in the field of cancer biology it is critical to establish an integrated picture that allows us to make working models for regulation. The review has done a perfect job towards this by providing two well designed figures. Overall it is a very timely review of this ever evolving field. It is really appreciated that the authors have provided a bit of introduction on what are miRNAs and what are Lnc RNAs. It will make it easy for readers that are new to this field to appreciate the review.

It is intriguing that the authors have provided a glimpse of future directions for the field. Overall I do not have any major or necessary suggestions. However I do have a curious request. Authors may wish to provide insight on if there is any way to integrate the miRNA based pathways to mRNA based pathways and if that has been done for P53 field.

Competing Interests: No competing interests were disclosed.

I confirm that I have read this submission and believe that I have an appropriate level of expertise to confirm that it is of an acceptable scientific standard.

Reviewer Report 20 May 2016

https://doi.org/10.5256/f1000research.8996.r13581

(C) 2016 Tanaka Y. This is an open access peer review report distributed under the terms of the Creative Commons Attribution License, which permits unrestricted use, distribution, and reproduction in any medium, provided the original work is properly cited. 


\section{Yuichiro Tanaka}

Department of Urology, San Francisco Veterans Affairs Medical Center, University of California, San Francisco, San Francisco, CA, USA

In this review, the authors systematically summarize the interplay between non-coding RNAs and the P53 pathway, with emphasis on how this affects gastrointestinal cancer. The non-coding RNAs are focused on miRNA and IncRNA, and how these both regulate and get regulated by P53.

The review is solid. The authors highlight each of the major miRNA or IncRNA involved with p53 in gastrointestinal cancer in a concise way. Mutant p53 and its effects on these noncoding RNA's are also discussed. They go into regulation of noncoding RNA or P53, not only by direct but indirect mechanisms and include genes involved in this regulation. They also touch up on noncoding RNA that have opposite effects depending on cancer type and thus, not biased. References are appropriate. The use of tables and figures highlight the key points made for each of the miRNA's and IncRNA's and thus, make it easier for the reader to follow.

Comment: The summary section is not really a summary of what was discussed. It is more of forthcoming ideas. Recommend adding a few sentences or a paragraph summarizing what was actually discussed since this is a summary section. This can then be followed by what is currently stated such as circular RNA, genomics technology and computational approaches, and the rest, as future approaches. Alternatively, the heading could be changed to "Future approaches" or something similar, if permissible.

Competing Interests: No competing interests were disclosed.

\section{I confirm that I have read this submission and believe that I have an appropriate level of expertise to confirm that it is of an acceptable scientific standard.}

The benefits of publishing with F1000Research:

- Your article is published within days, with no editorial bias

- You can publish traditional articles, null/negative results, case reports, data notes and more

- The peer review process is transparent and collaborative

- Your article is indexed in PubMed after passing peer review

- Dedicated customer support at every stage

For pre-submission enquiries, contact research@f1000.com 